\title{
DETERMINATION OF BLOOD LEVEL OF VITAMIN C IN CHRONIC RHEUMATIC DISEASE
}

\author{
BY
}

\author{
ENID A. M. BRADFORD
}

In juvenile rheumatism and rheumatoid arthritis, and in other infective conditions, it has been shown that vitamin-C levels are lower than in controls receiving the same intakes of the vitamin (Harris, 1937; and Rinehart, 1935, 1936, 1937). The extent of the fall in these rheumatic conditions is not so pronounced, however, as in certain other infective states, notably in acute pulmonary tuberculosis. Recent work of Mouriquand et al. (1938) in France and Kodicek and Murray (1943) at Cambridge on guinea-pigs suggests that there may be some hitherto unsuspected connection between abnormal bone growth and vitamin- $\mathrm{C}$ intake. The two last-named workers found that guinea-pigs on a prolonged partial deficiency of vitamin $\mathbf{C}$ (which was not severe enough to cause any symptoms of frank scurvy) showed a tendency to ankylotic change in the kneejoints after very slight injury. A minute trauma, such as would occur in merely handling the animals for taking x-ray records, was sufficient to set in motion a hyperplasia of connective tissue in the haemorrhagic area of the injury, which led to immobility and ankylosis of the joint. This effect was independent of vitamin D.

With these facts in view it seemed worth while to explore the hypothesis that a prolonged partial deficiency of vitamin $\mathrm{C}$ may be one of the possible factors involved in the genesis of rheumatic arthritis. The work of Bourne on repair of bone in vitamin-C deficiency (1942) is also interesting in this connection. In view of this experimental work on animals it is possible that some mild forms of pre-clinical scurvy may masquerade as rheumatism, since the symptoms of early scurvy in the adult human are weakness and pains in the limbs with subsequent skeletal lesions at the junction of bone and cartilage, loosening of the teeth, etc.

From the work of Daniels and Everson (1936) and Keith and Hickman (1938) it is known that the administration of aspirin lowers the renal threshold of vitamin- $C$ excretion, and practically all cases of arthritis take quantities of this drug to obtain relief. The successful control of rheumatic conditions may well require, among other factors, an adequate supply of vitamin $C$, and it is apparent that a wide field for research is open on this subject. Although clinical impressions are always open to uncertainty these results demonstrate the need for further observations on a statistical basis. In view of the practical difficulties of the usual saturation tests for patients attending an out-patient clinic the state of vitamin- $C$ nutrition has been investigated by determining the fasting blood level. Prunty and Vass (1943) have recently shown that this gives reliable information compared with urine saturation tests.

\section{Method}

The method of Deeny, Murdock, and Rogan (1942) was used with some minor modifications of technique necessary for pathological specimens. The object was to find a rapid method which would indicate the circulating level of vitamin $C$, and hence whole blood was used. This was thought preferable to plasma, which is more easily influenced by recent meals, or to white corpuscles, which present complications in the technique of separation from other constituents of blood, and of obtaining comparative results. Many of the blood samples examined caused trouble due to frothing in the preliminary treatment with coal gas, and also in obtaining a crystal-clear final solution for titration. These difficulties were largely overcome by reducing the initial gas treatment to five minutes before diluting with water, and prolonging the second gas treatment to ten minutes. The total exposure to coal gas was thus the same as in the original method. All samples were analysed within an hour of withdrawal. It is important that the metaphosphoric acid should be freshly prepared each day to ensure efficient precipitation of the proteins.

Titrations were carried out in small, straight-sided Jena glass test-tubes measuring $85 \mathrm{~mm} . \times 10 \mathrm{~mm}$. (Behring Venule tubes). With practice one tube can be used as control for the other duplicate by titrating against a white ground, which avoids the inaccuracy due to slight opalescence in the supernatant liquid from some pathological bloods. With these precautions an accuracy of $0 \cdot 1 \mathrm{mg}$. per $100 \mathrm{ml}$. blood is easily possible, and has been checked by comparative determinations.

\section{Results of Investigation}

There is some uncertainty as to standards for vitamin.C in blood. Since, however, according to various American workers (Abt et al., 1936; Faulkner, 1938; Wright, 1938; Goldsmith, 1939 and Todhunter, 1940) a normal level is considered to be from 1.0 to $1.2 \mathrm{mg}$. per $100 \mathrm{ml}$. of blood, and 
values between 0.5 to $1.0 \mathrm{mg}$. are taken by them to indicate a pre-scorbutic state, samples below $0.5 \mathrm{mg}$. per $100 \mathrm{ml}$. may be regarded for the present purposes, and without actual commitment as to the desirable levels, as " below the U.S.A. standard." The cases-Table $1 \mathrm{~A}$ - were taken at random during March and February, but as our experience grew a certain amount of selection was made in the light of the symptoms of patients showing low vitamin-C levels.

TABLE 1A

Vitamin C in Blood of Rheumatic Patients

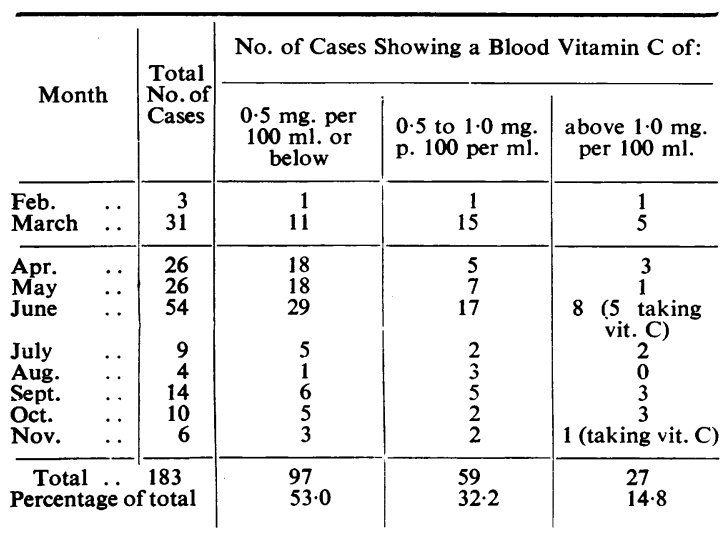

TABLE $1 B$

Blood Vitamin C in Normal Controls and Vegetarian Blood

\begin{tabular}{|c|c|c|c|c|}
\hline $\begin{array}{ll}\text { April } & \ldots \\
\text { May } & \ldots \\
\text { June } & \ldots \\
\text { July } & \ldots \\
\text { July } & \\
\text { Vegetarians }\end{array}$ & $\begin{array}{l}1 \\
3 \\
2 \\
4\end{array}$ & $\begin{array}{l}\mathbf{0} \\
\mathbf{0} \\
\mathbf{0} \\
\mathbf{0}\end{array}$ & $\begin{array}{l}1 \\
3 \\
2 \\
3 \\
0\end{array}$ & $\begin{array}{l}0 \\
0 \\
0 \\
1\end{array}$ \\
\hline Totals & 16 & 0 & 9 & 7 \\
\hline
\end{tabular}

The figures in Table 1A indicate that a large proportion of the patients attending the clinic have lower values for blood vitamin $\mathrm{C}$, even during May and June, when the level of intake is increased (Harris and Olliver, 1943), than the normals set out in Table $1 \mathrm{k}$. As a matter of routine every patient showing a blood vitamin-C level of less than $0.5 \mathrm{mg}$. per $100 \mathrm{ml}$, blood was treated with vitamin $C$ to produce saturation as follows: 1 st week -4 tablets (50 mg. ascorbic acid each) per day; 2nd week2 tablets (50 mg. ascorbic acid each) per day; followed by a maintenance dose of 1 tablet per day. The blood was removed in the morning about three hours after a light breakfast of tea and toast. When the patients had been taking vitamin- $\mathrm{C}$ tablets they were instructed not to take any tablets for 24 hours before coming for their second blood test, and a fasting sample was removed as before. Of the patients put upon this treatment twenty were retested, and all showed an increase of blood vitamin $\mathrm{C}$ to $1.0 \mathrm{mg}$. (or more) per $100 \mathrm{ml}$. In nine cases levels as high as 1.5 to $1.8 \mathrm{mg}$. per $100 \mathrm{ml}$. were reached. In most cases there was clinical improvement, especially where a low blood vitamin-C level was noted in the first place. These clinical symptoms were largely a relief of those symptoms mentioned in the survey-Table 3 ; but of the greatest effective use was the relief of "tiredness" - a feature which tends to be closely associated with rheumatic toxaemias and causes the most distress in present times. As a result of collaboration and discussion of these data with the physicians in charge of the cases it was evident that saturation with vitamin $C$ causes an improvement in general symptoms, especially noticeable when the condition was associated with a focus of infection.

The effect of a vegetarian diet on the blood level of vitamin $\mathrm{C}$ was studied in comparison with that of people on ordinary mixed diets, but exhibiting no symptoms of rheumatism. The results are given in Table 1B, and indicate that a purely vegetarian diet produces levels of blood vitamin $\mathrm{C}$ as high as those produced by treating patients with synthetic vitamin $\mathrm{C}$ with an intake of $200 \mathrm{mg}$. daily. This may perhaps lend some support to those who recommend a purely vegetarian diet for rheumatism. It must of course be remembered that the influence of vitamin $\mathrm{C}$ in rheumatic diseases is essentially only one aspect of a very much wider problem associated with other nutritional deficiencies or excesses.

A number of the samples of blood reported above were also tested in routine work by the differential sedimentation test (Coke, 1937). The sedimentation value so obtained was correlated with the vitamin-C level in the blood and with the clinical diagnosis at the same time as shown in Table 2.

TABLE 2

Correlation of Blood Vitamin C with Sedimentation Value

\begin{tabular}{|c|c|c|c|c|c|}
\hline Sedimentation Value & $1-10 \%$ & $11-20 \%$ & $21-30 \%$ & $31-40 \%$ & $41-70 \%$ \\
\hline No. of cases & 20 & 16 & 13 & 10 & 13 \\
\hline Mean vit. C & 0.75 & 0.47 & 0.53 & 0.39 & 0.40 \\
\hline $\begin{array}{l}\text { No. of cases above } \\
0.5 \mathrm{mg} \text {. per } 100 \mathrm{ml} \text {. }\end{array}$ & 11 & 4 & 8 & 1 & 3 \\
\hline
\end{tabular}

Diagnostic Means.-Active infective arthritis (41 cases) $-0.49 \mathrm{mg}$. p. $100 \mathrm{ml}$. Osteo-arthritis (16 cases) $-0.55 \mathrm{mg}$. p. $100 \mathrm{ml}$. Non-articular rheumatism (37 cases) $-0.58 \mathrm{mg}$. p. $100 \mathrm{ml}$.

It was observed that after the patients had been treated with vitamin $C$ the precipitation of blood proteins with metaphosphoric acid was much more efficient, giving crystal-clear solutions quite easily.

A survey was made of 75 patients submitted for vitamin-C tests with a view to ascertaining whether clinical symptoms could be correlated with a partial deficiency ( $c f$. Table 3).

TABLE 3

Correlation of Blood Vitamin C with Clinical Symptoms

\begin{tabular}{|c|c|c|c|}
\hline \multirow{2}{*}{ Symptoms } & \multicolumn{3}{|c|}{ No. of Cases Showing Blood Vitamin C. } \\
\hline & \begin{tabular}{|} 
Below $0.5 \mathrm{mg}$. \\
per $100 \mathrm{ml}$.
\end{tabular} & $\begin{array}{l}0.5-1.0 \mathrm{mg} . \\
\text { per } 100 \mathrm{ml} .\end{array}$ & $\begin{array}{l}\text { Above } 1.0 \mathrm{mg} . \\
\text { per } 100 \mathrm{ml} \text {. }\end{array}$ \\
\hline $\begin{array}{l}\text { Excessive tiredness ... } \\
\text { Sore gums } \ldots \\
\text { Spontaneous bruising } \\
\text { Very easy bruising ... } \\
\text { Anaemia . . } \\
\text { Endocrine disturbance } \\
\text { Gastric disturbance .. }\end{array}$ & $\begin{array}{r}31 \\
7 \\
4 \\
18 \\
9 \\
6 \\
15\end{array}$ & $\begin{array}{r}17 \\
4 \\
5 \\
11 \\
5 \\
4 \\
2\end{array}$ & $\begin{array}{r}12 \\
3 \\
4 \\
7 \\
1 \\
1 \\
7\end{array}$ \\
\hline
\end{tabular}
. 
The figures suggest that there was some positive correlation between low blood vitamin $\mathrm{C}$ and the following symptoms: (a) excessive tiredness, (b) tendency to bruising, and (c) gastric disturbances.

\section{Summary}

The blood level of vitamin $C$ in 183 cases of chronic rheumatic disease of different types has been determined, the symptoms recorded, and a method of saturation described. An apparent correlation was found between low vitamin-C levels and certain clinical symptoms; also, after saturation with vitamin $\mathbf{C}$ an improvement in general health is suggested from the records of clinical observations.

My thanks are due to Dr. Warren Crowe and Dr. Coke for much helpful advice and criticism, to Dr. Coke for the results of the D.S.T. tests in Table 2, to the Medical Staff of the Charterhouse Rheumatism Clinic for sending their patients to the laboratory for these examinations, and to the Council of the Charterhouse Rheumatism Clinic for permission to publish these results and for providing the facilities and means for carrying out the work.
I am indebted to Messrs. Roche Products for their kindness in supplying pure ascorbic acid, and to Messrs. Charles Hearson, Ltd., who designed and made a convenient rack for the gas treatment of a series of samples at the same time.

\section{REFERENCES}

Abbasy, Harris, and Hill (1936). Lancet, 2, 1413.

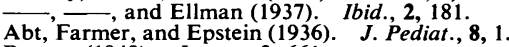
Abt, Farmer, and Epstein (1936).
Bourne (1942). Lancet, 2, 661.

Coke (1937). Charterhouse Rheumatism Clinic Papers, 1, 37. Daniels and Everson (1936). J. Nutrit., 12, 15.

Deeny, Murdoch, and Rogan (1942). Biochem. J., 36, 271.

Faulkner and Taylor (1938). J. clin. Invest., 17, 69.

Goldsmith and Ellinger (1939). Arch. internat. Med., 63, 531. Harris, et al. (1937). Lancet, 2, 177.

-, Passmore, and Pagel (1937). Ibid., 2, 183. (1941-2). Proc, roy. Soc. Med. 35,616.

and Olliver (1943). Lancet, 1,454 .

Keith and Hickmans (1938). Arch. Dis. Childh., 74, 125.

Keith and Hickmans (1938). Arch. Dis. Childh.,
Kodicek and Murray (1943). Nature, 151, 395.

Miller (1942). Lancet, 2, 563.

Mouriquand, Edel, d'Auvergne, and Lavand (1938). C. Rend. Soc. Biol., 129, 673.

Prunty and Vass (1943). Biochem. J. Proc., 37, 4.
Rinehart (1935). Ann. int. Med., 9, 671-689. , Greenberg, and Christie (1936). Proc. Soc. exp. Biol. Med., 35, $347-350$.

- (1937). Internat. Clin., 2, 22.

Todhunter and Robbins (1940). J. Nutrit., 19, 263.

Wright (1938). Ann. internat. Med., 12, 516. 